\title{
3. Epistemological vertigo and allegory: thoughts on massacres, actual, surrogate, and averted - Beersheba, Wake in Fright, Australia
}

\section{JOHN DOCKER}

Massacres of Indigenous people are both remembered and not remembered, creating in white Australian consciousness a confused energy around the ways Indigenous history is understood. ${ }^{1}$ Massacres occurred from the 1790s, early in British settlement of the continent, through the nineteenth century until well into the twentieth. Yet because this feature of Indigenous history is rarely faced directly or frankly, it emerges in popular culture indirectly, as in Freud's image of psychic unease, where that which is repressed will always find ways to disturb the surface of consciousness. What is feared is that one's society, if accused of having committed extreme violence, will suffer loss of honour among the nations. In this reading of Indigenous history I will look at what is not there, what is disregarded, minimised, and deflected.

In an essay on Edward Said, Ella Shohat uses the felicitous phrase epistemological vertigo to refer to how difficult it is for Jews, knowing themselves as a people of suffering and persecution, also to regard themselves as victimisers of others. It is a difficulty, she points out, that has been particularly posed in modernity by Zionist nationalism, whose aggressive settler colonialism in Palestine has made victims of both the Palestinians and also the Sephardim, the Arab Jews of the Middle East; and it is a vertigo, she reflects, that is also part of Euro-American historical consciousness, which cherishes an image of being anti-colonial since the nation foundationally gained its independence by freeing itself from imperial Britain. In each case, Shohat argues, the presence and civilisations of the Indigenous inhabitants, the Palestinians and the Native Americans in North America, are ignored or held to be of no account. ${ }^{2}$ In similar terms, Ann Curthoys evokes the power of victimology in white Australian popular

1 McKenna 2002

2 Shohat 1992: 134, also 140-141; Shohat 1988: 1-35; Shohat 2006: 201-232; Docker 2001: 141-142. 
historical consciousness and mythology, subtended by an uneasiness and anxiety that one's society not be perceived as a perpetrator nation in relation to its Indigenous peoples. ${ }^{3}$

Epistemological vertigo and allegory are drawn to each other, allegory suggesting phenomena that cannot be faced directly, that are displaced into other representations. Here I will explore how such allegorical displacement works in Australian historical consciousness in relation to Indigenous massacres.

The texts I will focus on are Paul Daley's book Beersheba: A Journey Through Australia's Forgotten War, published in 2009, concerning events in Palestine in 1917-1918; Baz Luhrmann's wonderfully provocative film Australia, referring to history in Central and Northern Australia between 1939 and 1941, which was released in late 2008; and another remarkable film, Wake in Fright, made in 1971 by the Canadian director Ted Kotcheff, beautifully restored and re-released in 2009. I want to think about three scenes of massacres actual, surrogate, and averted. The actual scene is the Arab massacre by Anzac forces, Australians and New Zealanders, in late 1918 in the Bedouin village of Surafend in Palestine. The other scenes are fictional and involve the massacre of kangaroos in Wake in Fright, and, averted at the last moment, of cattle in Australia, reminding us that, in terms of environmental history, massacre can involve slaughter of animals. Massacre indeed is etymologically associated with animals; the word traditionally used in France for the butcher's chopping block, in the sixteenth century it gained its modern meaning, which then spread from France to England. ${ }^{4}$

I will regard the three scenes of massacre in my chosen texts as allegorical. In terms of method, what interests me in exploring these texts, whether they are works of history like Beersheba or films like Wake in Fright and Australia, is the play of genre, textual tensions and stresses, ambivalences, narratives and counter narratives, stray details, obfuscations, and oddities. ${ }^{5}$

I suggest that a haunting dyad, legible in all three texts in different ways, of heroic values and dishonourable massacre, helps to shape, destabilise and bring incoherence to, white Australian historical memory and consciousness. The haunting can never be resolved and will always require new, impossible, attempts to create an unambiguous narrative. The textual result is confusion, even discursive and aesthetic chaos.

\footnotetext{
Curthoys 1999: 1-18; also Docker 2008a: 113-144.

Levene 1999: 7-9; also Greengrass 1999: 69.

Docker 2008a: 92.
} 


\section{Massacre studies and world history}

In the last several years I have been involved in genocide and massacre studies, 'world history' fields that are quite closely related, for both question and explore humanity at its limits; but they are also to some degree distinct. ${ }^{6}$ Genocide as a mode of inter-group violence frequently involves massacre, yet massacres can be a more diffuse phenomenon, involving, for example, as Mark Levene suggests in the introduction to The Massacre in History, the actions of a single individual. ${ }^{7}$ A feature of the field is what Jacques Semelin emphasises, the difficulty of explanation. ${ }^{8}$ We need to know more why in massacres groups suddenly turn on their neighbours with whom there may have been friendly relations for many years; we ask why massacres occur at certain times and not others; we wonder how massacres can be both carefully thought out and yet exhibit emotion and frenzy of an almost erotic kind; why they frequently involve the most appalling atrocities, as in mutilation, dismemberment, disembowelling, cannibalism, the drowning of or setting fire to victims; we observe that massacres often involve molestation of women including kidnapping, disfigurement, and rape. ${ }^{9}$

There is also the 'world history' question of the relationship between European colonisation and massacre. Massacres, as Lyndall Ryan and Ray Evans discuss so well in their essays in this book, were an integral part of the colonising of Australia, a primary and characteristic mode of what late twentieth century international law would identify as ethnic cleansing. Lyndall Ryan challenges historiography to recognise how frequently massacres were deployed as a means of destroying and clearing from desired land the continent's Indigenous societies and peoples. Ray Evans points to the recurring methods of the coloniser perpetrators, that they simultaneously acted and concealed evidence as they acted, especially in the burning of bodies. Colonial massacres, Evans reflects, were accompanied by codes of secrecy and silence, or obfuscatory language and indirect references; key records were lost; perpetrators already were or might become important men of standing in colonial society, commercially and politically. We can also note that the colonising of the Australian continent from late in the eighteenth century was preceded by centuries of European colonisation elsewhere, creating a repertoire of methods and techniques that included massacre, and many colonisers, soldiers of empire, and imperial administrators moved between various colonies. ${ }^{10}$ In these trans-empire and transcolonial terms, we can say that

6 Docker 2010.

7 Levene 1999: 1, 5.

8 Semelin 2003: 204, 208-209.

9 Semelin 2003: 208. For the massacres that frequently occur during partitions, see also Khan 2007; Pandey 2001.

10 Cf Lambert and Lester 2006: 24, note 94. 
from 1492, taken as a collective, the European colonisers of other peoples' lands, around the world, when they considered there was a need, proved themselves practised massacrists.

European colonisation has involved slaughter of both humans and animals. A glance at North America is helpful here.

Peter Coates, in his essay in The Massacre in History on the melancholy fate of the wolf in United States history, suggests that massacres of unwanted humans and predator animals like wolves (and coyotes and mountain lions) were, in the European settlement of North America from the Puritan seventeenth century onwards, part of a single spreading process of invasion, conquest, and subjugation. Through the centuries of colonisation, he observes, the most notorious massacres of humans involved non-whites, the main victims being Indigenous peoples. In animal terms, biocide was practised on a wide scale, the destruction of multiple wild species. Between 1492 and 1900, an estimated 60 to 75 million buffalo, held to be in the way of European crops and cattle, were reduced to about 500. Yet buffalo, Coates reflects, were not detested or mutilated. Native Americans sometimes were; and pathological hatred was also visible in the ruthless campaigns against wolves, where complete eradication was the goal. In colonial New England, Coates writes, the killing of Native Americans and of wolves was believed to be divinely sanctioned. In the organised campaigns against wolves, which reached their zenith in the region west of the Mississippi between the 1860s and the 1920s and employed shooting, trapping, poisoning, habitat clearance, torture and setting on fire, wolves were vilified in terms of pejorative human qualities reaching back into classical Greek antiquity (handed down from Aesop's fables) and early Christianity (the Bible casting the devil as the wolf from hell and enemies of the faith are wolves), and by association with hated human groups such as Native Americans. Settlers considered predator animals and Native Americans to have no claim on the continent, since, as hunters, they ranged across the land rather than inhabiting it. The triad of wolves, Native Americans, and wilderness was perceived, Coates says, as a threat to the civilisation the colonists felt they were establishing in North America from the time of the Puritan colonies onwards, its developing agricultural and pastoral economy of cattle, sheep, and wheat, and its social, cultural and spiritual health; the United States, as destined utopia and cornucopia, required their perpetual destruction and replacement. ${ }^{11}$

Coates's argument concerning destruction of Indigenous humans and animals and their landscapes and habitats, and their replacement by coloniser populations and their habitats and animal species, recalls Raphaël Lemkin's

11 Coates 1999: 163-173. 
originating definition of genocide. ${ }^{12}$ It also brings to mind Jared Diamond and Hugh Brody's 'world history' theories concerning the relentless spread for the last 8000 years of agricultural-commercial society across the planet, ruthlessly attempting to destroy all Indigenous hunter gatherer societies and ecologies in its path. In their argument, agricultural-commercial society is inspired by a mythos that the world belonged only to those who cultivated its land and dug into it for resources. ${ }^{13}$

\section{The Australian Light Horse: heroes, massacrists}

In Australian military history, the Light Horse who during World War I were so effective in campaigns against the Turkish (and German and Austrian) forces in Sinai, Palestine, and Syria, have been characteristically praised as legendary heroes, their courage, daring, resourcefulness, horsemanship, and impatience with (especially British) military hierarchy, being lauded as the result of their predominantly rural upbringing. While in Palestine, the Light Horse were under the immediate command of the Australian and imperial career soldier, general Sir HG (Harry) Chauvel, who in 1919 wrote the preface to a celebratory war history, Australia in Palestine, its editors HS Gullett and Chas Barratt. Here Chauvel enthuses that the Australian Light Horseman is of a 'type peculiarly his own and has no counterpart that I know of except in his New Zealand brother'. Chauvel feels that his 'fearlessness, initiative and endurance' are owing to the 'adventurous life he leads in his own country' where he has been accustomed to 'facing danger of all sorts from his earliest youth'; perhaps, Chauvel suggests, these qualities are 'inherited from his pioneer parents'. Chauvel also admires the Light Horseman for his 'good-fellowship and camaraderie', 'invariable good humour', and 'chivalry': all such exist in the 'free and open life of the Australian Bush' ${ }^{14}$ In such praise, the Indigenous peoples of Australia are nowhere in sight, except perhaps in the curious perhaps coded reference to the horseman 'facing danger of all sorts from his earliest youth', with its reverse narrative of threat to his rightful or assured presence on the land.

How could such men, with their superior rural values derived from their pioneer parents who were so important in the colonisation of the continent, commit a massacre when the war was already over and the Anzac horsemen were waiting to return to the antipodes? In his biography, Chauvel of the Light Horse, AJ Hill tells us that the 'tragedy' of Surafend was a 'bitter blow to Chauvel'. ${ }^{15}$

In 1923, HS (Henry) Gullett, as part of Australia's official war history under the general editorship of Charles Bean, published The Australian Imperial Force in

12 Lemkin 1944: 79-80.

13 Diamond 1992; Waswo 1997; Brody 2002; Dorrian: 27-51; Docker 2008a: chs 1 and 7.

14 Gullett and Barrett 1919: xiii.

15 Hill 1978: 192-193. 
Sinai and Palestine 1914-1918, where he constructs what we might call the urnarrative of the Surafend massacre, inscribing the strange mix, part exculpatory, part condemnatory, that provides the motifs, images and tropes for almost all succeeding purported descriptions of what occurred. Post armistice, in their camps at Tripoli and on the Philistine plain, after a very successful campaign that secured the defeat of the Ottoman forces in Sinai, Palestine, and Syria, the light horsemen, Gullett writes, participated in an 'unfortunate incident' that was destined to throw a 'shadow' over their last days in Palestine. It has to be recognised, however, he adds, that they were intolerably provoked, by the Indigenous inhabitants in one way, and the British high command in another; indeed, they should be regarded as victims of both. Next to the camps of the Anzac Mounted Division of Australians and New Zealanders lay 'the native village of Surafend', which elicits the following racial typing from Gullett: 'All the Arabs of western Palestine were thieves by instinct'. The 'natives of Surafend', he continues, 'were notorious for their petty thieving'. At night, the Australians and New Zealanders, 'sleeping soundly, were a simple prey to the cunning, barefooted robbers, and night after night men lost property from their tents'. In this image, the Light Horsemen are 'prey' to shoeless Arabs perceived as stealthy predatory scavengers. ${ }^{16}$

Furthermore, the British policy was, says Gullett, not to punish 'these debased people'. The British high command regarded them as 'devout Moslems, kin not only to the Arabs of the Hijaz' - a reference to the Arab army from southwest Arabia who, famously accompanied by TE Lawrence as British liaison officer, had revolted against the Turks and were fighting their way towards Damascus $^{17}$ - but also to 'the Mohammedans of India'. Gullett is here putting in place a key element of the ur-narrative: the interests of dominion soldiers like the Australians and New Zealanders were being demeaningly subordinated to the wider imperial interests of the British empire whose forces included many Indian soldiers, and where the Hijaz Arabs were allies with the British against the Turks. Furthermore, Gullett complains, 'the Arabs, a crafty race, quick to discern British unwillingness to punish their misdeeds, exploited their licence to extreme limits'; also, the British were unfairly disposed to blame the Australians for 'any looting' that occurred 'against the natives': an interesting admission that Anzac forces had been looting the local Bedouin people. ${ }^{18}$

Gullett's official history provides the template description of how the Surafend massacre occurred. ${ }^{19}$ As is often the case with massacres or scenes of violent retribution, a single individual of one's own group is injured or killed. In

16 Gullett 1923: 787-788.

17 Lawrence 1935[1926]; Lawrence 1927.

18 Gullett 1923: 787-788; Pappé 2004: 14-71; Doumani 1999: 11-40.

19 Perry 2009: 492-496. 
this case, a New Zealand soldier is shot by a Bedouin, 'the native' who had been stealing in his tent. The New Zealanders, their whole camp immediately aroused, and 'working with ominous deliberation', then trace the 'footsteps of the Arab' to Surafend. The New Zealanders throw a 'strong cordon' around the village, no Arab being allowed to leave. All day, Gullett says, the New Zealanders 'quietly organized for their work in Surafend', and then, early in the night, marched out 'many hundreds strong' and surrounded the village. In his narrative, Gullett stresses that only the male Bedouin were harmed. When they entered the village, the 'New Zealanders grimly passed out all the women and children', and then, 'armed chiefly with heavy sticks, fell upon the men and at the same time fired the houses'. Many Arabs, Gullett tells us, were killed and few escaped injury; the village was demolished and set on fire, and the flames from the 'wretched houses lit up the countryside'. The Anzacs next 'raided and burned the neighbouring nomad camp' and then went 'quietly back to their lines'. General Allenby and his staff, however, were stationed nearby, and could not fail to see the 'conflagration and hear the shouts of the troops and the cries of their victims' ${ }^{20}$

Gullett concedes that what happened 'cannot be justified', and affirms that Surafend 'should not be forgotten'. Nonetheless, he insists, 'in fairness to the New Zealanders, and to the Australians who gave them hearty support', we have to consider that the soldiers 'were the pioneers and the leaders in a long campaign'. They had just lost a 'veteran comrade' at the 'hands of a race they despised'; consequently, he feels, they became 'angry and bitter beyond sound reasoning' ${ }^{21}$

In terms of massacre studies, we can observe recognisable elements. The actions of the massacrists combine rational planning and frenzied action: the New Zealanders and Australians deliberate and organise all day; however, they also exhibit irrationality, for, as Gullett phrases it, they 'were angry and bitter beyond sound reasoning', though deliberation returns afterwards when they go 'quietly' back to their lines. They simultaneously conceal as they act: they 'fell upon the men', Gullett relates, and 'at the same time fired the houses', then 'raided and burned the neighbouring nomad camp'. Did they burn both to terrorise the villagers and neighbouring camp people, in a way that might recall Foucault's evocation at the beginning of Discipline and Punish of punishment as exemplary spectacle and warning, and to conceal evidence of what they had done? Burning of bodies was characteristic of the massacres that the colonisers of Indigenous Australia had perpetrated - the history of genocide and massacre conducted by the white pioneers the Light Horse were heir to. ${ }^{22}$ 
Gullett also reveals, while sharing in it, the racism of the Light Horse towards the Indigenous Palestinians, a feature of coloniser attitudes that was strongly part of nineteenth century and especially rural Australian history; when Gullett says that 'the shouts of the troops' could be heard, did such shouting include ugly racist imprecations?

Surafend has become a source of unease even agony for those who fervently wish to see the Light Horse as deserving of the same honour and recognition as Gallipoli in Australian military and national history. Egregiously, the Light Horse as they killed and burned had gone from how they wished to perceive themselves, as victims of the Bedouin and British, to being dishonourable victimisers. The consequences were immediate. In searing memory of the soldiers there, General Allenby, as the British commander-in-chief of the Egyptian Expeditionary Force, told the assembled Light Horse that he once had admired them but he admired them no more; they had revealed themselves to be cold-blooded murderers. The soldiers felt that because of his anger over Surafend, Allenby in future years unfairly denied the Light Horse the battle honours and rewards they deserved, and in doing so was enacting on the whole Light Horse a form of collective punishment given that only a portion were involved. ${ }^{23}$ (The Anzacs themselves, we might note, had enacted collective punishment on a whole village and nearby camp for the actions of one man.) In the writing of military history, there was from the beginning attempts to censor or minimise mention of Surafend. Lachlan Coleman reports that Gullett wrote to Bean protesting at Chauvel's attempts to censor what he was writing about Surafend, with Bean writing back that Gullett should tell the story for, if not, 'you would be concealing from Australians a truth'; it is of interest that Coleman says that the Light Horse used bayonets as well as clubs and picks. ${ }^{24}$ DM Wyatt, a retired soldier and military historian, notes that in 1919 Brigadier General Cox, later a prominent federal parliamentarian, addressed the members of the 3rd Light Horse Regiment, which had been directly involved in Surafend, with the advice, 'We will speak of this incident no more', though, Wyatt adds, Surafend had lingered in the minds of surviving members of the regiment for the rest of their lives. Wyatt reveals that it had been suggested to him that he should not discuss Surafend. ${ }^{25}$

Surafend has long been referred to as an incident, the usual term for it in Australian military history. I suggest, however, that for Australian history the significance of the massacre and burning of the Indigenous Palestinian village and camp is as a displaced allegory of the settler colonisation of Indigenous Australia. A potent reason, that is, why information, discussion, and memory

23 Gullett 1923: 787-791; Jones 2007: 198; Coleman 2007: 62.

24 Coleman 2007: 62-63.

25 Wyatt 2006: 96-101. 
have been so repressed is that Surafend questions heroic narratives both of the Australian Light Horse in Palestine and of white settlement in Australia. In even more far-reaching terms, Surafend is an allegory of all settler colonialism which, in Raphaël Lemkin's view, as I have contended elsewhere, necessarily involves genocide and massacre as a technique of genocide. ${ }^{26}$

For the Palestinians, the massacre was a harbinger of more massacres to come, of a tragic history.

\section{Surafend, Gallipoli and Israel}

One text that does not share the relegation of the Surafend massacre to an 'unfortunate incident', as Gullett had referred to it, is Paul Daley's Beersheba: A Journey through Australia's Forgotten War (2009). It is an engagingly personal exploration of the Australian Light Horse in Sinai and Palestine. A senior journalist, Daley begins his journey as an outsider to Australian military history, and this gives his text a certain detachment. Doubts and uncertainties fissure Beersheba between a positive narrative of the Light Horse and a counter narrative of alternative perspectives that erode the author's initial confidence; the result is a kind of perturbed polyphonic text of unresolved attitudes, of anxiety towards histories the author had set out to admire. Daley explains early on that, in comparison to Gallipoli, he had barely heard of the Charge of Beersheba, but once he began his research into it he wanted to challenge the 'Gallipoli-centric Anzac story'. He also confesses that he had never heard of Surafend, until, as part of his research, he goes to interview (in 'benign Australian suburbia') Chanan Reich, an 'Israeli academic who specialises in relations between his country and Australia'. They talk about Beersheba for a while, and then the Israeli academic suddenly asks Daley, does he know about the massacre by the Australians. With that question, Daley says, his story was set on a different course. ${ }^{27}$ Now he will wonder how the 'myth and legend' of the Australian Light Horse can be reconciled with a 'shameful' act of 'extreme cowardice and premeditated violence' $?^{28} \mathrm{He}$ will ponder if it is because of this massacre that the Charge of Beersheba, once considered a famous military victory, the last great cavalry charge in history, barely features in popular Australian mythology, in contrast to Gallipoli, a military defeat. ${ }^{29}$

\footnotetext{
26 Cf Docker 2008b: 81-101.

27 Daley 2009: 1-7.

28 Daley 2009: 8.

29 Excerpts from Beersheba appeared in the Sydney Morning Herald, 25 July 2009, Good Weekend section, entitled 'One Bloody Secret'. In the Good Weekend's letters page of 15 August 2009, Caroline Graham, a keen student of the Australian Light Horse in the Middle East, wrote: 'My great-uncle was in the Australian Light Horse and I have much admiration for the troops' courage. But Paul Daley is right in "One Bloody Secret" (July 25): raising topics such as the Surafend massacre is "uncomfortable". I presented my own research on the Light Horse at a conference in 1987, mentioning Surafend and other misdeeds, such as the burning of villages
} 
His research into Surafend presents Daley with disturbing questions about the massacre and the conduct of the Light Horse in Palestine, which he explores in the last third or so of the book, not least the 'premeditated nature of the crime' and the 'lingering cover-up' that ensued for decades afterwards. Daley is appalled by the way the Australians covered for each other after the massacre, denying to the military courts of enquiry that any of them were there, and 'comprehensively' blaming the New Zealanders in a 'breathtaking and farcical' way. The most remarkable and unsettling perspective about the behavior of the Light Horse comes when Daley listens to the tape of an interview between the army historian Doug Wyatt, referred to above, and trooper Harold 'Ted' O'Brien, of the 3rd Light Horse Regiment's C Squadron, which had comprised mainly men from Tasmania. Even though Wyatt had not asked him. O'Brien, now a very old man, suddenly begins very agitatedly to talk about Surafend. ${ }^{30}$

O'Brien admits to being there during the massacre, that he was a perpetrator, with tortured memories of the extreme brutality of war. After the New Zealand sergeant was killed by a Bedouin, the old soldier relates, the New Zealanders and Australians went out to the village and 'went through it with a bayonet'. Wyatt asks O'Brien if the Tasmanian Light Horse were involved: 'Oh yes. Our squadron was there. I was down there. I don't know what I did with it, I was cranky and that. But they had a good issue of rum and they did their blocks', O'Brien repeats, reminding us of Ray Evans' observations about massacre perpetrators in the colonisation of Australia, 'Yeah, I was there, but I don't know if I did anything like that'. Wyatt asks what did the Light Horse, who had drunk rum and where 'everyone did their block', actually do in Surafend? O'Brien tells him that there were cows, ducks, geese, and 'kids' there, but the Light Horse 'all went for the men with the bayonet and they got it' ${ }^{31}$

At the very least, then, as often occurs in massacres, the children were forced to watch their fathers and male relatives being murdered. Were any women there, a question that interests Wyatt: 'The women then moved out, I suppose?' O'Brien replies, rather mystifyingly: 'There were some left. And they trekked out. They left their village and they went away. It was a bad thing. It was a real bad thing.' ${ }^{32}$ If there were women there, as well as kids, did they too have to watch their husbands, brothers, uncles and sons over a certain age, being killed by the New Zealanders and Australians who had lost their blocks?

in post-war Egypt. My paper was attacked in the press back then; I hope Paul Daley gets a better reception. It's just that up till now we have avoided unpalatable truths.' Caroline Graham, 'One Bloody Secret', Good Weekend, Sydney Morning Herald, 15 August 2009.

30 Daley 2009: 252, 267, 270, 273.

31 Daley 2009: 274-276.

32 Daley 2009: 276. 
O'Brien also tells Wyatt how much the Light Horse disliked the 'wicked' Bedouins. Because the Light Horse did not know what side the Bedouin were on, they were 'treated as enemies', and so, 'You'd shoot them on sight.'33

As well as Surafend, O'Brien reveals other horrific memories, of behaviour including his own that he now thinks was 'ungodly'. In particular he describes the time when he stabbed a dying Turkish soldier in the stomach so that he could rob him when dead: 'we used to go through them - you know. ... we was going to rob the dead sort of business'. O'Brien relates in detail how he and his mates looted coins from the dead and also used Turkish bodies for target practice: 'We used to pot-shot them and you would see them up like that and they'd bounce. Oh, dear, it was a bit of sport' ${ }^{34}$

A final observation. In Beersheba the author travels back and forth between Australia and Israel, the Beersheba battle field being near the modern Israeli city of Be'er Sheva in the Negev. In Israel, Daley meets Israelis who celebrate the Light Horse charge at Beersheba in 1917 because in their view it paved the way for the British Mandate, which enabled mass Jewish immigration and Zionist political and military organisation, and then the 1948 War of Independence and the founding of the Jewish state. He also meets Christian fundamentalists like Kelvin Crombie, an Australian who believes that the Light Horse's victory has prepared the way for the return of the Messiah to the holy land, and who has for many years conducted guided tours of the Light Horse scene of heroism. ${ }^{35}$

What Daley's book does not explore is an idea suggested by his inquiries and experiences, that there is an affinity between Australia and Israel as two settler colonial societies with an inevitable history of massacre of their indigenous peoples. Beersheba reveals no awareness - here is a limit to its polyphony - of the work of Israeli New Historians such as Ilan Pappé, who in his groundbreaking The Ethnic Cleansing of Palestine (2006), evokes how much of the ethnic cleansing of 1948, that which the Palestinians refer to as the Nakba, the disaster, was done by massacre, including the massacre of a village, Dawaymeh, near Beersheba. ${ }^{36}$

\footnotetext{
33 Daley 2009: 275.

34 Daley 2009: 274-276.

35 Daley 2009: 192-193. Cf Crombie 1998: 368: 'Perhaps in fact those Jewish and Christian Bible-believing people have been right. Perhaps the return of the Jewish people to the Land of Israel, and more specifically to Jerusalem, may lead to the final conflict of the ages and be a prelude to the coming, or return of the Messiah.' 36 Pappé 2006: 195-197, also refers readers to 'The Dawaymeh Massacre', the report by the UN's Palestine Conciliation Commission of 14 June 1949, now accessible on the Internet, which observes that the massacre was, in many respects, 'more brutal than the Deir Yassin massacre'. In the Sydney Morning Herald, 14 November 2009, Good Weekend, p. 38, a Palestinian-Australian, Rihab Charida, refers to how, in 1948, when her father was nine, his Palestinian village, Safsaf, was assaulted by Zionist forces, her father witnessing 'a massacre where men from the village were lined up and shot.' Rihab Charida refers to the diaries of an Israeli officer, Yosef Nahmani, who wrote that 50-60 villagers were shot and several women raped. She also tells of a trip in 2004 where she hired a car and drove to the village; Rihab rang her father on her mobile phone, and when
} 
When asked about the women at Surafend, Ted O'Brien had said, 'There were some left. And they trekked out. They left their village and they went away.' We can pause to wonder if any of the women who were survivors of the massacre at Surafend made their way to the village of Dawaymeh, thence to experience the horror of mass killing for a second time.

\section{A surrogate massacre: Wake in Fright}

'Hey, the Americans killed every buffalo in the country and almost wiped out every Indian tribe' ('Wake in Fright: An Interview with Ted Kotcheff', 27 May 2009) $)^{37}$

Let us glance at the now notorious kangaroo massacre scene in Wake in Fright, set in a fictional Australian outback town and its red earth surrounds. Its director a Canadian who has spent most of his working life in London, Wake in Fright is a coruscatingly brilliant film, a profoundly unsettling study of Australian male society of the late 1960s (it was shot in 1969, much of it in Broken Hill). The film explores the ironic possibilities of the Bildungsroman, a study of disintegration where the chief character, John Grant (Gary Bond), an emblematic figure of the intellectual as outsider, learns how desperately much he wants to be an insider, to become part of the embrace of homosociality. The unnerving intensity of Wake in Fright inheres in its unstable generic elements, in particular social realism mixing with the poetics of excess of baroque. Walter Benjamin, discussing in The Origin of German Tragic Drama the Baroque theatre, literature and art of the seventeenth century, suggests that baroque reveals an agonising violence of style, an eccentric mode that revels in its own visuality and theatricality, in extravagance and exaggeration; its spectacles create a characteristic feeling of vertigo. Benjamin likens baroque to early twentiethcentury German Expressionism. ${ }^{38}$

Briefly, Wake in Fright creates a world where John Grant, middle-class, well spoken in an educated almost 'English' voice, bookish, chooses to gamble with all his pay, at an all male two-up game, hoping if he wins to return to the city and be released from his teaching bond with the Education Department. He loses almost all his money, and by the end of the film owns little but his city suit, now dusty and ragged, and a rifle. While Grant occasionally sarcastically protests against the pressures to conformity in the working class culture he is invited to join, it becomes clear that he also desires it. Once the men realise he wishes to

she began to evoke the surrounding hill and mountains, he interrupted his daughter and described the rest of the scene as he remembered it. 'At least', Rihab's father said, 'my voice has made it home.' Concerning the massacre of Safsaf, see Pappé 2006: 184-185.

37 Kotcheff 2009. In the interview, Kotcheff says: 'I'm Canadian and Canada has the same British colonial background as Australia'.

38 Benjamin 1996: 49-51, 54-56; Docker 2001: 191, 218. 
be part of them, they are indeed friendly and welcoming. We see Grant at every step enjoying a masculinist desire to be drawn into exclusive company with other men, gambling and drinking beer, indeed drinking, drinking, drinking. The men drink beer in the all-male hotel bars, at parties, on trains, anywhere they can. Like his new mates, Grant now becomes completely indifferent to the women of the outback, including Janette, the young woman at a party who invites him to take a walk and make love, in a bizarrely passive and joyless way; but Grant, having imbibed for hours with the men at the party, is too drunk and vomits nearby. Women, we see, are to be ignored because they interrupt male sociality, they draw men away from the group, they might divide men. There is, however, no male violence towards women, indeed the men reveal no interest in them in any way, they are regarded as powerless and irrelevant, and the women, leading separate lives, like Janette or two young women in a hotel foyer, appear insuperably bored.

There is, nevertheless, a great deal of violence in Wake in Fright, either enacted or implied. As a kind of rite of passage into their world, a group of men he gets to know at the party where he fails Janette, invites Grant to drive with them into the bush for a kangaroo shoot. Interpreted through the settler-colonial focus of massacre studies, they wish to kill an Indigenous animal perceived by the settlers as vermin, a competitor for their introduced plant-eating animals. At this point, Grant's membership of male society is strengthened by his being given a gun by one of the kangaroo shooters. The group includes the miners Dick (Jack Thompson) and Joe (Peter Whittle) as well as Doc Tydon (Donald Pleasance), who has given up medicine for his ruling passion, beer. The graphic joyful slaughter, very hard to watch, culminates in Grant being set a final test of membership, to kill a kangaroo by hand with a knife; reluctant at first, because he sees it is very young and already injured, he launches into a frenzied stabbing and mutilation. After the kangaroo hunt, the men drive back to an old hotel, shoot it up with their rifles, drink beer till they are ecstatically awash with it, fight and embrace each other, while the ex-doctor stands on his head and pours beer into his mouth. Beer becomes like the fabled inland sea, an alternative to the coastal waters next to which city people exist. Grant in the film dreams for a moment of being at Bondi with his city girlfriend Robyn. In this dreammemory, Robyn is confident, strong, active, looking down on a prone John Grant lying on the beach, a powerful Aphrodite figure rising from the waves. The city is associated with water as a principle of female vitality. The outback is associated with beer as a kind of water surrogate, flowing over the men's faces, hair, clothes, bodies. It is also associated with guns, Grant keeping his rifle, to be treasured as iconic of his membership of the male group, in his suitcase. The Doctor is also an emblematic figure who, standing on his head drinking, inverts all his education and training, as might in the future happen with the 
Teacher; they are drawn to each other as minds on the edge of nothingness. The kangaroo massacre culminates in what Kotcheff in interview refers to as Doc Tydon's sexual assault of Grant.

In Wake in Fright the kangaroo massacre is, in my view, a surrogate for the actual historical massacres of Australia's Indigenous peoples, leaving the hauntingly empty landscape that we see at the beginning and end of the film. I should make it clear that I am not arguing that killing kangaroos as such, for example for food, is wrong. What I am suggesting is that the white men's erotic delight in slaughtering the kangaroos recalls the genocide and massacre studies historian Dan Stone's theories of collective effervescence in mass killing, an enjoyment of violence and the theatre of violence, the perpetrators experiencing a heightened sense of belonging to their own group. ${ }^{39}$ In general in the film, the male group works by a hierarchy of racial inequality. The group is not composed solely of Anglo men, there are European migrant men as well, that is, there is a kind of inclusive coloniser cosmopolitanism at work, where hospitality and group membership are extended to an Englishman like Doc Tydon or white males from Europe.$^{40}$ Clearly lower in the male hierarchy, however, is the Chinese cook called 'Chink' we glimpse for a moment in the café, preparing meals for the gamblers whose faces are studies in rapt concentration. We also do see Indigenous characters, a child in the school at the beginning, a man on a pub verandah, though they have no speaking parts. There is, however, a key scene on a train. Near Grant is an old Indigenous man, sitting alone, who looks out the window at the empty landscape and begins to sing a melancholy song. Here Grant, the educated outsider, could have kept the company of another outsider. ${ }^{41}$ But then a festive group of white men also in the carriage throw Grant a beer, he catches it and joins them. He immediately gives in to their ressentiment, their desire to accept him only if he is like them and does what they do, because - he now knows of himself - his keenest desire is not to be perceived as an outsider or be an outsider. The solitary old Indigenous man sings quietly mournfully on, in a train passing by a landscape which once his ancestors had peopled as their cosmos. $^{42}$

Wake in Fright appeared in 1971 during a late 1960s, early 1970s time when conventional viewpoints, and modes of masculinity and femininity, in Australian

39 Stone 2004: 45-65; Stone 2006: 211.

40 Concerning coloniser cosmopolitanism in relation to hospitality, see Waswo 1997: 138, 140-148; Docker 2008a: 170-171, 183, 218 .

41 Kotcheff 2009 relates that 'the point of having the Aboriginal person is that he, too, is felt to be outside the community, and so there is identification between the two. That both are outsiders was the point I was trying to make.'

42 Ashenden recalls a similar moment in The Overlanders (1946), directed for Ealing Studios by the British director Harry Watt. An Aboriginal stockman is heard chanting; asked what he is singing about, the film's heroine Mary Parsons replies: 'About the time these people owned the land probably. When they were happy.' Ashenden 2008: 2-3. 
society were being challenged with the rise of the New Left, the counter culture, Indigenous-led activism and critiques of racial discrimination. An intellectual culture and new histories arose that were sharply critical of received attitudes towards women, gender, sexuality, Indigenous dispossession, anti-Asian racism, and the sending by governments of Australian troops to support imperial wars like the American war in Vietnam. ${ }^{43}$ John Grant, the intellectual in the outback, chose to succumb to conformity, while the alternative intellectual cultures gaining in analytic strength and theoretical sophistication chose to be like the cultural figure in Georg Simmel's famous essay 'The Stranger', outside and inside their society at the same time. ${ }^{44}$

\section{A massacre averted: Baz Luhrmann's Australia}

It is, I think, precisely the new intellectual culture of the 1960s and beyond, challenging Australian settler colonialism as a project of nationalism and racism, that influences Baz Luhrmann's Australia. The film is, as we would expect from Luhrmann, a kind of postmodern extravaganza. In its poetics of excess, it is always drawing attention to its own theatricality, of parody and self-parody. It is also highly allusive and intertextual, including, as a kind of choric refrain, references to scenes and a tune ('Somewhere over the Rainbow') from The Wizard of $\mathrm{Oz}$, which came out in 1939, the year when the film's actions begin. As in Wake in Fright, characters are emblematic figures rather than psychological portraits. The film reveals almost a surplus of mixed generic elements. Its establishing phases draw on burlesque and vaudeville, visible especially in Nicole Kidman's mode of acting, when her character, Lady Ashley, owner of Faraway Downs a cattle station in central Australia, arrives in the outback. She is a female version of a New Chum, an upper class English person to be made fun of by hardened locals, including he whom she will engage in a conflictual romance with, the Drover (Hugh Jackman). Towards the end of the film, there is transformation and metamorphosis. The final sequence of scenes are set in Darwin and on a church-run island mission nearby, to which are sent abducted Indigenous children, including Nullah (Brandon Walters), the 12-year-old Indigenous boy who is a hero of the film. Now mock epic and mock romance move into epic with its war scenography, and melodrama where characters represent extremes and undergo extremes. ${ }^{45}$

Let us quickly create a conversation between Wake in Fright and Australia. Each presents itself as a kind of parable, a creation story, yet Australia, coming out nearly four decades later, questions and inverts many of the patterns and attitudes of the earlier film, especially in terms of 'race' and also gender.

43 Cf Docker 1988: 289-307.

44 Wolff 1950: 402-408; Docker 2001: 86-87, 125.

45 Cf Docker 1994: 252; Brooks 1976: 4, 35, 54. 
Where in Wake in Fright the white male community is the centre of the film's actions and observations, and Indigenous people and non-Indigenous women are marginalised (I cannot recall any sighting of Indigenous women in Wake in Fright), in Australia, the reverse occurs. The film begins with Nullah as narrator explaining that the 'white fellas' say he is a 'half caste', and that if he is caught by the police he will be taken away to the mission island near Darwin, highlighting the plight of the Stolen Generations as central to Australian history. Nullah's father is the villainous Fletcher (David Wenham), who wishes to usurp Faraway Downs for himself, and refuses to acknowledge Nullah as his son: much later in the film, Lady Ashley, at an upper class ball held in Darwin to raise funds for the taking of children to the mission island, publicly draws attention to the refusal of white fathers to acknowledge their paternity, scandalising the upper class women there. ${ }^{46}$ Never far away from Nullah is his grandfather, King George (David Gulpilil), a kind of choric commentator and spiritual guide whose Indigenous language is translated in sub-titles. In terms of gender, Lady Ashley as English aristocrat and owner of a huge cattle station is at the centre of the film, an elite woman with considerable power to widen the possibilities of what women can do. After Nullah's mother drowns while trying to keep him concealed from the police who have come to take him away, Lady Ashley becomes increasingly maternal in her regard for him. For quite a while in the movie, however, she insists, against the advice of the Drover, that Nullah cannot leave her and Faraway Downs and go with, as he wishes to, his grandfather into Arnhem Land to learn Indigenous cultural knowledge to do with country, ceremony and stories. 'You belong here', she says to Nullah, to the consternation of Drover, raising the general question of colonisation and belonging.

Lady Ashley's assimilationist desire here is an obstacle that strains her relationship with Drover. For his part, Drover has to overcome a legendary Australian male desire, that we glimpse in Wake in Fright in relation to the Teacher and Janette or the Teacher's apparent loss of interest in his city girlfriend, not to commit to relationships with women. We can recognise Drover as a cultural figure stepping intact out of the pages of Russel Ward's radical nationalist The Australian Legend (1958), which had famously contended that out on the western plains, far from Australia's coastal cities, a nomad tribe of (white) bush workers had developed a mystique formative for the nation as a whole, of egalitarianism, hospitality, mateship, independence, skepticism. Ward observed that the legendary Australian male was a rolling stone, without the impediment of family. ${ }^{47}$ 'No man hires me, noone fires me', the Drover ritually insists, and he is only dissuaded from this legendary view by his Indigenous co-drover, brother

46 Cf Curthoys 2002: 109. Lady Ashley also scandalises the upper class women at the ball by wearing a red cheongsam, perhaps a reference to Tracey Moffatt's famous haunting image of a woman in a Chinese red dress. 47 Ward 1966[1958]: 1-2, 13, 254-255; Docker 1984: 15-16, 36, 119. 
in law and friend, Magarri (David Ngoombujarra). The Drover has fought in World War I, but when he returns he learns his Indigenous wife, Magarri's sister, had died, since no white hospital (in a possible allusion for American audiences to what happened to Billie Holiday) had been willing to accept her as a patient. Magarri, perhaps upholding Indigenous values stressing kinship, family and relationships, upbraids the Drover for insisting on his independence when he clearly loves Lady Ashley. The Drover is alienated from his fellow white drovers because he mainly keeps the company of his Indigenous relatives and friends; as he says, the other white drovers see him as black, and he in turn detests their ugly racism and their support for discriminatory practices like Indigenous people being refused service in hotel bars. Here, in his anti-racism, is the Drover's difference from Russel Ward's legendary figure.

In this conversation between Wake in Fright and Australia, then, a major difference is clear: in Wake in Fright, the men in the outback town form a closed androcentric community which excludes white women and Indigenous people. In Australia, it is les autres, les étrangers, Indigenous and non-Indigenous, male and female - Nullah, King George, Drover, Magaree, Nullah's female relatives including Bandy, Lady Ashley - drawn together in their desire to save Nullah from being captured by the police, who form an alternative community to conventional white coloniser society. Also, the heroism we associate with epic is distributed across and amongst all of those in this alternative community, it certainly does not inhere only in the Drover. It is Nullah's supreme moment of heroism that I focus on here, reprising motifs of massacre studies. Recall that King Carney the cattle baron has ordered his employee Fletcher, a pure melodrama principle of evil, and some of his drovers, those who despise the Drover for being too friendly with Indigenous people, to prevent Faraway Down's cattle being delivered to Darwin. They attempt to do this by poisoning water holes and by fire, frightening the cattle into stampeding towards the edge of a precipice. Nullah, at the edge of the cliff, using Indigenous powers taught him by his grandfather, who is nearby, sings the cattle into quietness and submission, averting their mass death. Nullah's foot, however, nearly slips, for a frightening moment we think he might fall and die. It is difficult, watching these scenes, not to think that there is an allusion to a well-known and distressing feature of massacres of Indigenous groups in Australian history, often involving in memory and story their being driven over cliffs, with perhaps the only survivor a child, to be taken away by the coloniser massacrists. When Nullah averts the massacre of cattle and is embraced as a hero by those who admire and love him, including a Madonna and child scene with Lady Ashleigh, a kind of pietà, there is perhaps a surrogate wish fulfillment that the long history of massacres of Indigenous peoples, often at the edge of cliffs, did not (have to) happen. More generally, the suggestion in the film is that the history of extreme 
violence against the continent's Indigenous peoples would not have happened if the European colonisers had had the attitudes the good white characters in the film now possess. ${ }^{48}$

In Wake in Fright, the animals massacred had been kangaroos, an Indigenous herbivore and a competitor to animals such as cattle brought in by the colonisers in an act of ecological genocide. In Australia, Nullah saves cattle, in a kind of utopian vision where pro-Indigenous Australians and Indigenous Australians come together in a common effort that includes a settler-colonial pastoral economy that has replaced the Indigenous economy and its relationships to land. However, by film's end, Lady Ashley agrees that Nullah should go with his grandfather to Arnhem Land to learn vital cultural knowledge. The film, that is, does not try to reconcile a depressing contradiction between loss of economy and cultural continuity. While the genocidal loss of Indigenous economy, it would appear, has to be historically accepted, the continuance of Indigenous cultural knowledge is now valued as profoundly important. Yet, we might think, how can there be continuity when there is no economic basis sustaining it? (Here we might think of scenes of desolation and boredom in a remote town in Central Australia in Warwick Thornton's superb Samson and Delilah, released in 2009.)

However, when in Australia Darwin and the nearby mission island are attacked by invading Japanese, the stolen children and the largely white Australian society created in the film become common victims, with fires burning in the town as well as on the ships in the harbour. Sympathy that had ebbed away from the socially conventional white characters in relation to Indigenous people can now return as they share suffering and death.

In this aspect, the film ends on a note more in tune with the legend of Gallipoli, of Australians as a whole as victims, a perpetrator society that, mythologically, is not a perpetrator society.

\section{References}

Ashenden, Dean 2008, 'Luhrmann, us, and them', Inside Story, 18 December 2008: 1-5.

Benjamin, Walter 1996, The Origin of German Tragic Drama, John Osborne (trans), Verso, London.

48 Garry Maddox, 'Luhrmann's happy ending to an Australian story', Sydney Morning Herald, Weekend Edition, 8-9 August 2009, relates that before casting Walters as Nullah in the film, Luhrmann visited the family in their Kimberley homeland; he was invited back for the handover in June 2009 of native title to almost 40,000 square kilometres of land to the Nyangumarta community, which includes the family of Brandon Walters. 
Brody, Hugh 2002, The Other Side of Eden: Hunter-Gatherers, Farmers, and the Shaping of the World, Faber and Faber, London.

Brooks, Peter 1976, The Melodramatic Imagination: Balzac, Henry James, Melodrama, and the Mode of Excess, Yale University Press, New Haven.

Coates, Peter 1999, “Unusually cunning, vicious and treacherous": the extermination of the wolf in United States history', in The Massacre in History, Mark Levene and Penny Roberts (eds), Berghahn Books, New York: 163-183.

Coleman, Lachlan 2007, 'The Surafend Incident: not all of the ANZAC story is laudable', Wartime: Official Magazine of the Australian War Memorial 39: 62-63.

Crombie, Kelvin 1998, Anzacs, Empires and Israel's Restoration 1798-1948, Vocational Education and Training Publications, Perth.

Curthoys, Ann 1999, 'Expulsion, exodus, and exile in white Australian historical mythology', in Imaginary Homelands: The Dubious Cartographies of Australian Identity, Richard Nile and Michael Williams (eds), University of Queensland Press, Brisbane: 1-18.

— 2002, Freedom Ride: A Freedom Rider Remembers, Allen \& Unwin, Sydney.

Daley, Paul 2009, Beersheba: A Journey through Australia's Forgotten War, Melbourne University Press, Melbourne.

Diamond, Jared 1992, The Rise and Fall of the Third Chimpanzee, Vintage, London.

Docker, John 1984, In a Critical Condition, Penguin Books, Melbourne.

- 1988, "Those halcyon days": the moment of the New Left', in Intellectual Movements and Australian Society, Brian Head and James Walter (eds), Oxford University Press, Melbourne: 289-307.

- 1994, Postmodernism and Popular Culture: A Cultural History, Cambridge University Press, Melbourne.

— 2001, 1492: The Poetics of Diaspora, Continuum, London.

— 2008a, The Origins of Violence: Religion, History and Genocide, Pluto, London.

- 2008b, 'Are settler-colonies inherently genocidal? Re-reading Lemkin', in Empire, Colony, Genocide: Conquest, Occupation, and Subaltern Resistance in World History, A Dirk Moses (ed), Berghahn, New York: 81-101. 
- 2010, 'The origins of massacres', in Theatres of Violence: Massacre, Mass Killing, and Atrocity in History, Philip Dwyer and Lyndall Ryan (eds), Berghahn Books, New York: in prep.

Dorrian, Mark 2001, 'On some spatial aspects of the colonial discourse on Ireland', The Journal of Architecture 6: 27-51.

Doumani, Beshara B 1999, 'Rediscovering Ottoman Palestine: writing Palestinians into history', in The Israel/Palestine Question, Ilan Pappé (ed), Routledge, London: 11-40.

Greengrass, Mark, 1999, 'Hidden transcripts: secret histories and personal testimonies of religious violence in the French wars of religion', in Mark Levene and Penny Roberts (eds), The Massacre in History, Berghahn Books, New York: 69-88.

Gullett, HS 1923, The Australian Imperial Force in Sinai and Palestine 19141918, Angus and Robertson, Sydney.

— and Chas Barrett (eds) 1919, Australia in Palestine, Angus and Robertson, Sydney.

Hill, AJ 1978, Chauvel of the Light Horse: A Biography of General Sir Harry Chauvel, G.C.M.G., K.C.B., Melbourne University Press, Melbourne.

Jones, Ian 2007, A Thousand Miles of Battles: The Saga of the Australian Light Horse in WWI, ANZAC Day Commemoration Committee, Queensland.

Khan, Yasmin 2007, The Great Partition: The Making of India and Pakistan, Yale University Press, New Haven.

Kotcheff, Ted 2009, 'Wake in Fright: An interview with Raffaele Caputo', Senses of Cinema, online journal, no 51, <www.sensesofcinema.com/2009/featurarticles/ted-kotcheff-interview/>

Lambert, David, and Alan Lester (eds) 2006, Colonial Lives Across the British Empire: Imperial Careering in the Long Nineteenth Century, Cambridge University Press, Cambridge.

Lawrence, TE 1927, Revolt in the Desert, Jonathan Cape, London.

— 1935[1926], Seven Pillars of Wisdom, Doubleday, Doran and Co, New York.

Lemkin, Raphaël 1944, Axis Rule in Occupied Europe: Laws of Occupation, Analysis of Government, Proposals for Redress, Columbia University Press, New York. 
Levene, Mark 1999, 'Introduction', in The Massacre in History, Mark Levene and Penny Roberts (eds), Berghahn Books, New York: 1-38.

— and Penny Roberts (eds) 1999, The Massacre in History, Berghahn Books, New York.

McKenna, Mark 2002, Looking for Blackfellas' Point: an Australian History of Place, University of New South Wales Press, Sydney.

Moses, A Dirk (ed) 2004, Genocide and Settler Society: Frontier Violence and Stolen Indigenous Children in Australian History, Berghahn, New York.

- (ed) 2008, Empire, Colony, Genocide: Conquest, Occupation, and Subaltern Resistance in World History, Berghahn, New York.

Pandey, Gyanendra 2001, Remembering Partition: Violence, Nationalism and History in India, Cambridge University Press, Cambridge.

Pappé, Ilan (ed) 1999, The Israel/Palestine Question, Routledge, London.

- 2004, A History of Modern Palestine: One Land, Two Peoples, Cambridge University Press, Cambridge.

— 2006, The Ethnic Cleansing of Palestine, Oneworld, Oxford.

Perry, Roland 2009, The Australian Light Horse, Hachette Australia, Sydney.

Semelin, Jacques 2003, 'Towards a vocabulary of massacre and genocide', Journal of Genocide Research 5.

Shohat, Ella 1988, 'Sephardim in Israel: Zionism from the standpoint of its Jewish Victims', Social Text 19/20, Autumn: 1-35.

- 1992, 'Antinomies of exile: Said at the frontiers of national narrations', in Edward Said: A Critical Reader, Michael Sprinker (ed), Blackwell, Oxford: 121-143.

— 2006, Taboo Memories, Diasporic Voices, Duke University Press, Durham.

Stone, Dan 2004, 'Genocide as transgression', European Journal of Social Theory 7: 45-65.

- 2006, History, Memory and Mass Atrocity: Essays on the Holocaust and Genocide, Vallentine Mitchell, London.

Ward, Russel 1966[1958], The Australian Legend, Oxford University Press, Melbourne. 
Passionate Histories

Waswo, Richard 1997, The Founding Legend of Western Civilization: From Virgil to Vietnam, Wesleyan University Press, Hanover.

Wolff, Kurt H (ed and trans) 1950, The Sociology of Georg Simmel, The Free Press, Glencoe, IL.

Wyatt, DM 2006, 'The Surafend Incident', in Tasmania's A.I.F. Lighthorsemen, Peter James Pickering (ed), Self-published, Hobart: 96-101. 